\title{
Analysis of molecular aberrations of Wnt pathway gladiators in colorectal cancer in the Kashmiri population
}

\author{
A. Syed Sameer, ${ }^{1,2}$ Zaffar A. Shah,' Safiya Abdullah,' Nissar A. Chowdri ${ }^{3}$ and Mushtaq A. Siddiqi ${ }^{*}$ \\ 'Department of Immunology and Molecular Medicine, Sher-I-Kashmir Institute of Medical Sciences, Soura, Srinagar, Kashmir, \\ 190011, India \\ ${ }^{2}$ Department of Clinical Biochemistry, Sher-I-Kashmir Institute of Medical Sciences, Soura, Srinagar, Kashmir, 190011, India \\ ${ }^{3}$ Department of General Surgery, Sher-I-Kashmir Institute of Medical Sciences, Soura, Srinagar, Kashmir, 190011, India \\ *Correspondence to: Tel: +91 194240 1013, Ext 2262; Fax: +91 194 2403470; E-mail: mousvi786@gmail.com/vc.tmuk@gmail.com
}

Date received (in revised form): 17th March 2011

\begin{abstract}
The development and progression of colorectal cancer (CRC) is a multi-step process, and the Wnt pathways with its two molecular gladiators adenomatous polyposis coli (APC) and $\beta$-catenin plays an important role in transforming a normal tissue into a malignant one. In this study, we aimed to investigate the role of aberrations in the APC and $\beta$-catenin genes in the pathogenesis of CRC in the Kashmir valley, and to correlate it with various clinicopathological variables. We examined the paired tumour and normal-tissue specimens of $86 \mathrm{CRC}$ patients for the occurrence of aberrations in the mutation cluster region (MCR) of the APC gene and exon 3 of the $\beta$-catenin gene by polymerase chain reaction-single-strand conformation polymorphism (PCR-SSCP) and/or PCR-direct sequencing. Analysis of promoter hypermethylation of the APC gene was also carried out using methylation-specific PCR (MS-PCR). The overall mutation rate of the MCR of the APC gene among 86 CRC cases was 12.8 per cent (II of 86). Promoter hypermethylation of APC was observed in 54.65 per cent (47 of 86) of cases. Furthermore, we found a significant association between tumour location, tumour grade and node status and the methylation status of the APC gene $(p \leq 0.05)$. Although the number of mutations in the APC and $\beta$-catenin genes in our CRC cases was very low, the study confirms the role of epigenetic gene silencing of the pivotal molecular gladiator, APC, of the Wnt pathway in the development of CRC in the Kashmiri population.
\end{abstract}

Keywords: Wnt pathway, APC, $\beta$-catenin, colorectal cancer, Kashmir, hypermethylation, mutations, Dukes' stage

\section{Introduction}

Colorectal cancer (CRC) is a major cause of mortality and morbidity, and the third most common malignancy in the world. ${ }^{1}$ The incidence of this malignancy shows considerable variation among racially or ethnically defined populations in multiracial/ethnic countries. It is the fourth most common cancer in men and the third most common in women worldwide. ${ }^{1}$ Kashmir has been reported as being a high-incidence area for gastrointestinal (GIT) cancers. $^{2,3}$ In the Kashmir valley,
CRC represents the third most common GIT cancer after oesophageal and gastric cancer. ${ }^{4,5}$

It has been suggested that CRC is a multi-step process which arises from cumulative aberrations of a number of different genes (including tumour suppressor genes, proto-oncogenes, DNA repair genes, the genes encoding growth factors and their receptors, cell cycle checkpoint genes and apoptosis-related genes) or from epigenetic changes in DNA at different stages of development and progression. ${ }^{6,7}$. It is 
believed that mutations in the gene encoding adenomatous polyposis coli (APC) or that encoding $\beta$-catenin set the stage for the initiation and transformation of normal colonic epithelial cells. Further accumulation of mutations in other genes then contributes to the progression of cancer through adenoma - carcinoma - metastasis stages. The generally accepted model of CRC tumorigenesis for the majority of tumours has been a stepwise progression, in which mutations in APC are followed by several other mutations, including alterations in the genes encoding Kirsten ras (K-ras) and tumour protein 53 (TP53). ${ }^{6-8}$ During the accumulation of genetic changes, a complex signalling network is established among inactivated and activated cellular pathways. ${ }^{9}$

The Wnt pathway regulates cell adhesion, morphology, proliferation, migration and structural remodelling ${ }^{9,10}$ and plays an important role in a variety of cellular processes, including proliferation, differentiation, survival, apoptosis and cell motility. ${ }^{11}$ Loss of regulation of the Wnt pathway has been implicated in the development of several types of cancers, including colon, lung, breast, thyroid and prostate cancers and leukemia. ${ }^{12-15}$ Two of the most important gladiator molecules of the Wnt pathway are $A P C$ and $\beta$-catenin.

$A P C$ is a classical tumour suppressor gene, located on $5 \mathrm{q} 21$, containing 21 exons. The APC transcript is 9.0 kilobases $(\mathrm{kb})$ in length and the most common isoform of the APC protein contains 2,843 amino acids, with a molecular weight of $310 \mathrm{kD}$. Exon 15 of $A P C$ is most important, as it comprises $>75$ per cent of the coding sequence of $A P C$ and hence is the common target for both germline and somatic mutations, which usually span codons $1286-1513$ of this exon. ${ }^{16,17}$ This region represents the mutation cluster region (MCR), and 68-77 per cent of somatic mutations in $A P C$ occur in this region. ${ }^{18}$ Mutations in $A P C$ are considered to be the earliest genetic aberrations in the initiation and progression of CRC, ${ }^{7,9,19}$ and have also been found in $\sim 60-80$ per cent of sporadic carcinomas and adenomas. ${ }^{20,21}$ Using mutant mouse models, various genetic studies have demonstrated that mutations in $A P C$ are responsible for intestinal tumorigenesis. ${ }^{22-24}$ Homozygous $A P C$ mutations in mice lead to embryonic lethality, ${ }^{23,25,26}$ and conditional deletion of the gene in the adult mouse disrupts homeostasis, not only in the intestines but also in other tissues. ${ }^{27-29}$

In addition to the mutational inactivation, hypermethylation of the gene promoter is another important mechanism associated with gene silencing. ${ }^{30}$ In many tumours the hypermethylation of $\mathrm{CpG}$ islands in gene promoters has been found to be a frequent epigenetic change in cancers, and is usually associated with the loss of transcription of $A P C .^{31-38}$ Hypermethylation of the APC gene promoters has been reported in about $20-48$ per cent of human CRCs. ${ }^{32,37,39,40}$

The $\beta$-catenin gene is located at $3 \mathrm{p} 22-\mathrm{p} 21.3$ and encompasses $23.2 \mathrm{~kb}$ of DNA. It contains 16 exons, with a mRNA transcript of about 2343 base pairs (bp), encoding a 781-amino-acid-residue protein with a molecular weight of $92 \mathrm{kD} .{ }^{41}$ This gene is mutated in up to 10 per cent of all sporadic CRC by point mutations or in frame deletions of the serine and threonine residues that are phosphorylated by glycogen synthase kinase 3-beta (GSK3 $\beta){ }^{42}$ These mutations result in the stabilisation of $\beta$-catenin and the activation of Wnt signalling. Mutations in the $\beta$-catenin gene occur in exclusivity to $A P C$ aberrations, as both molecules are components of the same pathway. ${ }^{19}$

Based on the hypothesis that CRC carcinogenesis is a multi-step and multi-gene event, we designed this study to elucidate the role of $A P C$ and $\beta$-catenin in the development and progression of CRC in the Kashmiri population, and to correlate the gene aberrations and hypermethylation with the clinicopathological parameters of CRC cases.

\section{Materials and methods}

\section{Patients and specimens}

Out of 104 patients who were diagnosed with CRC by clinicians using either sigmoidoscopy or colonoscopy and confirmed by MRI, a total of 86 CRC tissue specimens, comprising tumour tissues and corresponding adjacent normal tissues as controls, were collected for analysis. All samples were surgically resected and collected fresh at the Department 
of Surgery of the Sher-I-Kashmir Institute of Medical Sciences, Srinagar, Kashmir. Tissue samples were divided into two parts; one part was sent for histopathological diagnosis and the other was snapfrozen at $-70^{\circ} \mathrm{C}$ immediately until needed for further analysis. Only histopathologically confirmed cases were included for molecular analysis. No follow-up of the CRC patients was carried out after the curative surgery. Written informed consent was obtained from all the subjects (and/or their guardians) included in the study, recorded on a predesigned questionnaire (available on request). The study was carried out in accordance with the principles of the Helsinki Declaration. The study protocol was approved by the Research Ethics Committee of the Sher-I-Kashmir Institute of Medical Sciences, Kashmir.

\section{DNA isolation}

Genomic DNA was extracted from blood and tissue samples (previously stored at $-70^{\circ} \mathrm{C}$ ) from CRC patients using DNA Extraction Kit II (Zymo Research, Orange, CA). The tissue for DNA extraction from the tumour sample was chosen by an experienced pathologist and was ascertained to comprise more than 90 per cent of the tumour cells.

\section{Polymerase chain reaction (PCR)}

$A P C$ and $\beta$-catenin gene analysis was carried out on all of the extracted DNA samples. The MCR region of $A P C$, comprising codons 1260 to 1596, and exon 3 of $\beta$-catenin, which encompasses the region for GSK-3 $\beta$ phosphorylation, were amplified using specific oligonucleotide primers (Table 1). PCR was performed in a $50 \mu \mathrm{l}$ total volume reaction mixture containing $50 \mathrm{ng}$ of genomic DNA, $100 \mathrm{ng}$ of each primer, $100 \mu \mathrm{M}$ of each deoxynucleotide triphosphate $(\mathrm{dNTP}), 1.5 \mathrm{mM} \mathrm{MgCl} 2,10 \times$ Taq buffer and $2 \mathrm{U}$ of Taq DNA polymerase (Fermentas Inc, Glen Burnie, MD). The conditions of PCR were as follows: initial denaturation at $95^{\circ} \mathrm{C}$ for 5 minutes, 35 cycles of denaturation at $95^{\circ} \mathrm{C}$, annealing at $52-58^{\circ} \mathrm{C}$ (see Table 1) and extension at $72^{\circ} \mathrm{C}$, for 30 seconds each, and final extension at $72^{\circ} \mathrm{C}$ for
7 minutes in a Biorad icycler. The PCR products were run on 2-3 per cent agarose gel and analysed under an ultraviolet illuminator.

\section{Mutation analysis of the $A P C$ gene}

Mutation analysis of the $A P C$ gene was performed on all cases. Four sets of oligonucleotide primers that have previously been reported were used for fragment-wise amplification (APCA, B, C and D) of codons 1260 to $1596 .^{43}$ All amplicons were $300 \mathrm{bp}$ in length (Figure 1A-D, Table 1), and were then subjected to single-strand conformation polymorphism (SSCP) analysis. For the samples showing an aberrant band in the SSCP analysis, $A P C$ BF and $A P C$ DR primers were used to amplify the $890 \mathrm{bp}$ target region (Figure 1E) and then were subjected to direct sequencing (Macrogen Inc, Seoul, Korea), including the original $300 \mathrm{bp}$ amplicons; however, studying the aberrations of only the MCR was a limitation of this study.

\section{Mutation analysis of the $\boldsymbol{\beta}$-catenin gene}

Genomic DNA from each sample was amplified by PCR using the previously reported primer pair, which amplified a 200-bp amplicon of exon 3 of the $\beta$-catenin gene (Figure 2A, Table 1). ${ }^{43}$

Base substitutions in codons 32 and 33 were further confirmed by the Hinfl restriction endonuclease assay (Fermentas). The 200-bp PCR product for $\beta$-catenin contains two Hinfl restriction endonuclease sites, yielding 7-bp, 55-bp and 138-bp DNA fragments after digestion of the wild-type allele. $\beta$-catenin gene mutations in codons 32 and 33 yield only 62-bp and 138-bp fragments after digestion because of ablation of the first Hinfl site. The digested products were run on 10 per cent polyacrylamide gel electrophoresis (PAGE) (Figure 2B) to assess the digested fragments.

\section{SSCP analysis}

SSCP analysis of PCR products was carried out on 6 per cent non-denaturing polyacrylamide gel (PAG) utilising either non-radioactive silver staining or radioactive procedures, as explained 
Table I. Primer sequences used for the mutational analysis of $\beta$-catenin and APC genes in the Wnt pathway

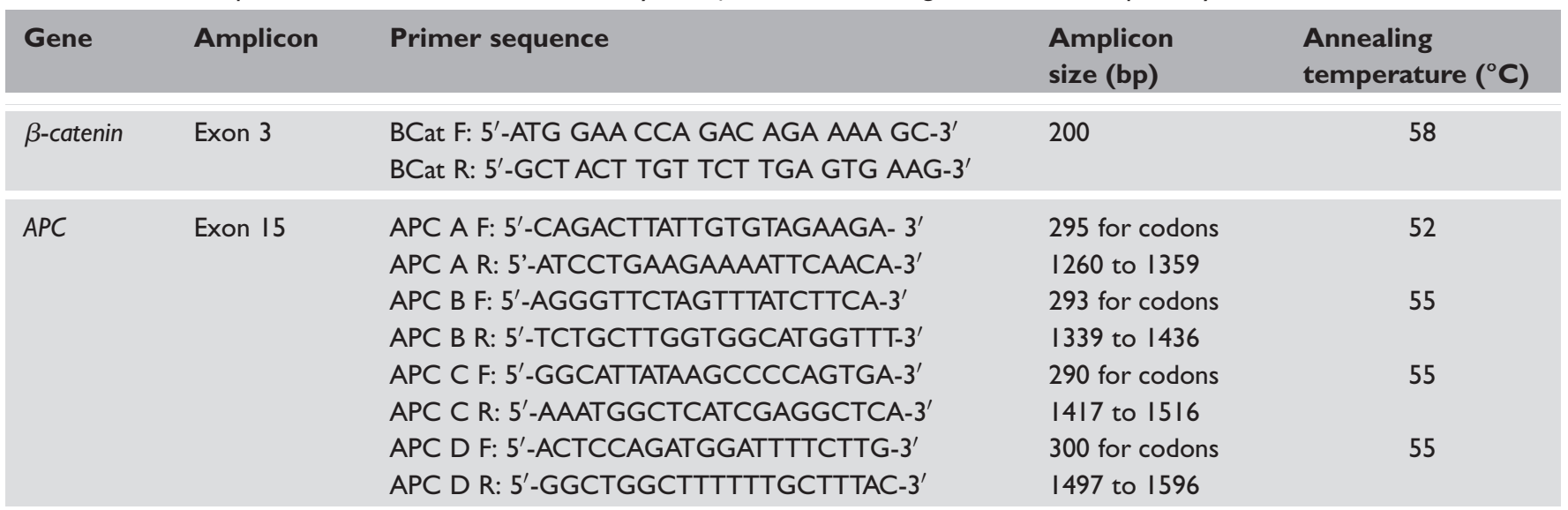

previously. $^{4,44}$ In non-radioactive SSCP analysis, PCR products were mixed together in denaturing buffer (95 per cent formamide, $10 \mathrm{mM} \mathrm{NaOH}$, 0.05 per cent xylene-cyanol FF and 0.05 per cent bromophenol blue) in a 1:1 ratio, heat denatured at $95^{\circ} \mathrm{C}$ for 5 minutes and immediately cooled on ice for 20 minutes. Of the resulting product, $6 \mu l$ was loaded on 6 per cent PAG and electrophoresed in $0.5 \times$ Tris-borate EDTA buffer at $\pm 17^{\circ} \mathrm{C}$ at $4 \mathrm{~W}$ constant power for 18-22 hours. Gels were then silver stained. In radioactive SSCP analysis, radiolabelled PCR products (using $\alpha 32-\mathrm{pCTP}$ ) were mixed in a denaturing loading buffer (95 per cent formamide, $20 \mathrm{mM}$ EDTA, 0.05 per cent xylene-cyanol FF and 0.05 per cent bromophenol blue) in a $1: 10$ ratio and heat denatured at $95^{\circ} \mathrm{C}$ for 5 minutes. Of the resulting product, $3 \mu \mathrm{l}$ was loaded on 6 per cent PAG and electrophoresed at $4 \mathrm{~W}$ constant power in $0.5 \times$ Tris-borate ethylene diamine tetra-acetic acid (EDTA) buffer at $\pm 17^{\circ} \mathrm{C}$ for 18-22 hours. The gel was then transferred onto $3 \mathrm{~mm}$ Whatman paper, covered with Saran wrap

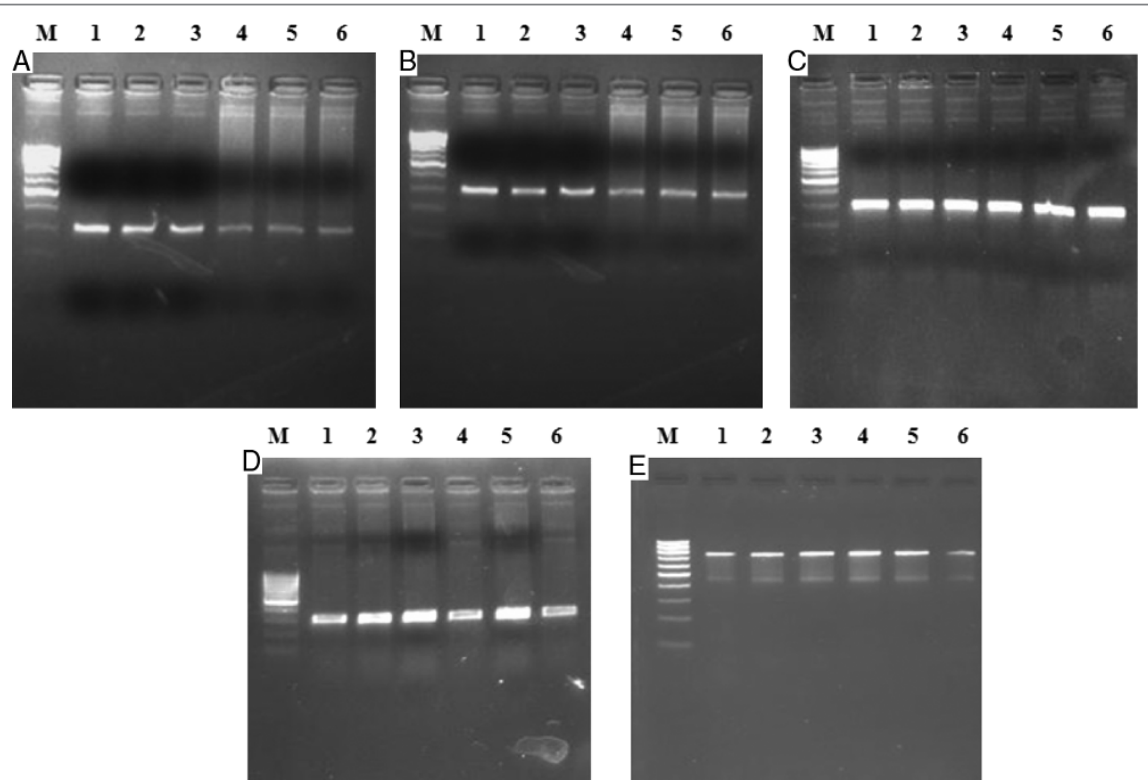

Figure IA-E. Representative gel picture of mutation cluster regions of APC gene comprising of Exon I5 APCA (295bp); APCB (293bp); APCC (290bp); APCD (295bp); and APC Full (890bp) fragments. Lane M: Molecular size marker I00bp (Middle Prominent Band =500bp) Lane I-6: Amplified product from cancer samples. 


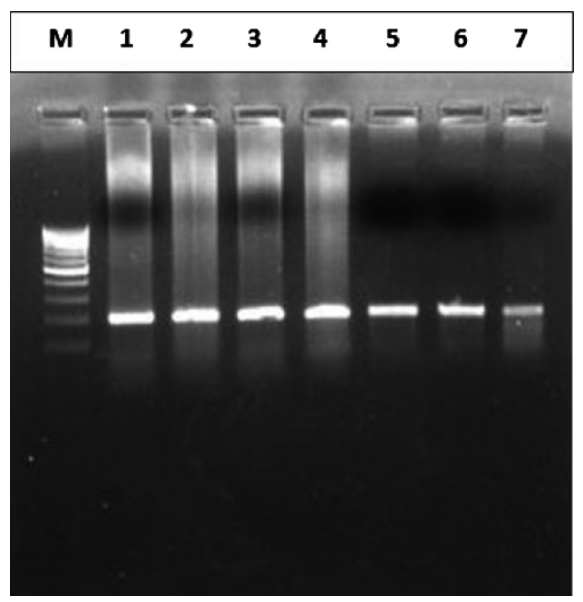

Figure 2A. Amplified DNA fragment (200 bp amplicon) of exon 3 of $\beta$-catenin gene. Lane M: 100 bp molecular ladder, Lanes I-7: Amplicons from different tumour tissues.

and dried in a vacuum drier at $90^{\circ} \mathrm{C}$ for 1 hour. The Saran wrap was then replaced by X-ray film and kept at $-70^{\circ} \mathrm{C}$ for 48 hours.

The mobility shift in DNA bands was visualised by developing the X-ray film. Purified PCR products of the samples showing mobility shift on SSCP analysis and randomly chosen samples were used for direct DNA sequencing.

\section{Methylation-specific PCR (MS-PCR) of $A P C$ promoters}

Both normal and tumour DNAs were subjected to sodium bisulphite modification using the EZ DNA Methylation Kit (Zymo Research, Irvine, CA).

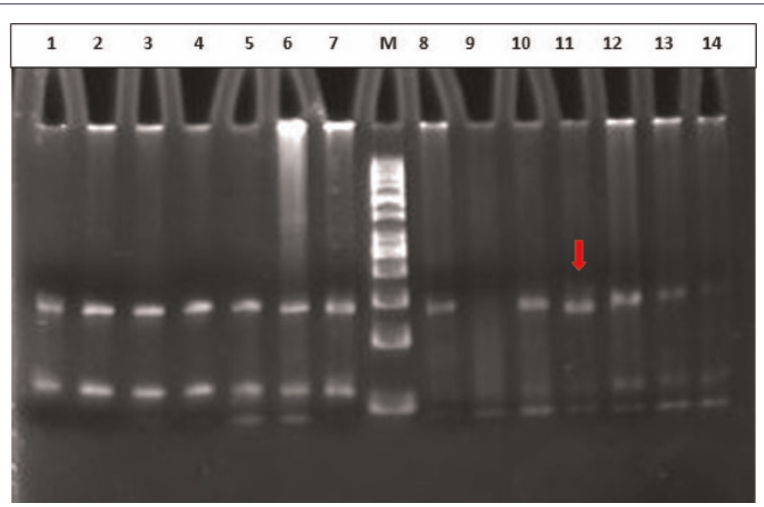

Figure 2B. PAGE analysis of Hinf I digest of $200 \mathrm{bp}$ amplicon of exon 3 of the $\beta$-catenin gene. Lane M: 100 bp molecular ladder, Lanes I-14: Hinfl digested amplicons of the $\beta$-catenin gene. Lane II shows the codon 32 mutant.
About 10 ul of DNA from each sample was modified as described in the protocol. Previously reported primer sets were used for amplification of the two promoters $-1 \mathrm{~A}$ and $1 \mathrm{~B}$ of the $A P C$ gene (Table 2). ${ }^{32,37}$

PCR was performed in a $50 \mu \mathrm{l}$ total volume reaction mixture containing $10 \mathrm{ng}$ of modified genomic DNA, $100 \mathrm{ng}$ of each primer, $100 \mu \mathrm{M}$ of each dNTP, $1.5 \mathrm{mM} \mathrm{MgCl}_{2}$, 5 per cent dimethyl sulphoxide (DMSO), $10 \times$ Taq buffer and $2 \mathrm{U}$ of Taq DNA polymerase (Fermentas). The reactions were hot started at $97^{\circ} \mathrm{C}$ for 10 minutes before the addition of 0.75 units of Taq polymerase (Fermentas). The PCR conditions were as follows: 40 cycles of denaturation at $95^{\circ} \mathrm{C}$ for 40 seconds, annealing at the temperatures specified in Table 1 for 45 seconds, extension at $72^{\circ} \mathrm{C}$ for 45 seconds and a final extension at $72^{\circ} \mathrm{C}$ for 10 minutes to complete each PCR. The PCR amplicons were electrophoresed on 2.5 per cent agarose gels and were visualised after staining with ethidium bromide (Figure 3A and 3B).

Universal Methylated Human DNA (Zymo Research) was used as positive control for methylated alleles whereas DNA from normal lymphocytes was used as a control for unmethylated alleles. Water was used as a negative PCR control in both reactions.

\section{Direct sequencing}

PCR amplicons of the tumour samples and from randomly chosen normal samples were first purified using the DNA Recovery Kit (Zymo Research) and then used for direct DNA sequencing. DNA sequencing was carried out at Macrogen Inc. To minimise the sequencing artefacts by PCR, amplicons from at least two different PCRs were sequenced using forward and reverse primers.

\section{Statistical analysis}

All statistical analysis was performed using PASW software, version 18 (IBM, New York, NY). Pearson's chi-square two-proportion test was used to evaluate the hypothesis of equal distribution of molecular alterations with different 
Table 2. Primer sequences used for hypermethylation analysis of the promoter region of the APC gene

\begin{tabular}{|c|c|c|c|c|}
\hline Gene & Amplicon & Primer sequence & $\begin{array}{l}\text { Amplicon } \\
\text { size (bp) }\end{array}$ & $\begin{array}{l}\text { Annealing } \\
\text { temperature }\left({ }^{\circ} \mathrm{C}\right)\end{array}$ \\
\hline \multirow[t]{4}{*}{$A P C$} & IA & APC IA UF: 5'-TGTTTTATTGTGGAGTGTGGGTT-3' & 108 & 60 \\
\hline & Promoter & APC IA UR: 5'-CCAATCAACAAACTCCCAACAA- $3^{\prime}$ & & \\
\hline & & APC IA MF: 5'-TATTGCGGAGTGCGGGTC-3' & 98 & 55 \\
\hline & & APC IA MR: 5'-TCGACGAACTCCCGACGA-3' & & \\
\hline \multirow[t]{4}{*}{$A P C$} & IB & APC IB UF: 5'-GATAGAATAGTGAATGAGTGTTT-3' & 195 & 55 \\
\hline & Promoter & APC IB UR: 5'-CTTCCAACAACCACACCCCA-3' & & \\
\hline & & APC IB MF: 5'-TAGAATAGCGAACGAGTGTTC-3' & 190 & 55 \\
\hline & & APC IB MR: 5'-TCCGACGACCACACCCCG-3' & & \\
\hline
\end{tabular}

clinicopathological variables. A Fisher's two-tailed test ( $p$ values) of 0.05 or less was considered to be statistically significant.

\section{Results}

Of 86 confirmed cases of CRC, 38 were of Dukes' $\mathrm{A}+\mathrm{B}$ stage and 48 were of $\mathrm{C}+\mathrm{D}$ stage. All patients presented with constipation and bleeding per rectum as their chief complaint. Furthermore, 81 of these cases were sporadic, four had familial adenomatous polyposis and one had Lynch syndrome. All but one case had adenocarcinoma and only one had squamous cell carcinoma (SCC) of

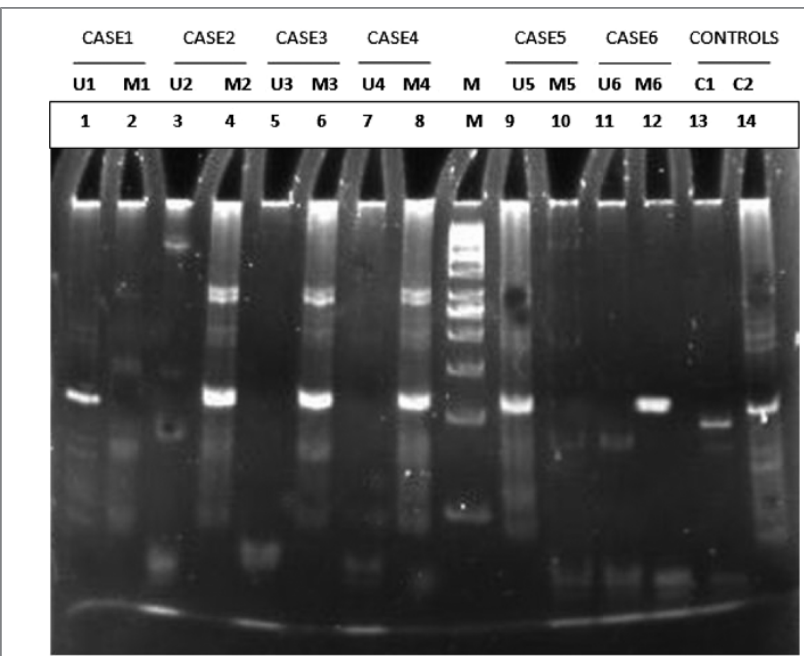

Figure 3A. PAGE analysis of APC IA promoter methylation. Lane M: 50 bp molecular ladder Lanes I- 14: amplicons from paired samples. Case I and 5: Unmethylated APC IA promoter Cases 2, 3, 4 and 6: Methylated APC IA promoter $\mathrm{Cl}$ and $\mathrm{C2}$ : Internal unmethylated and methylated human DNA controls. the basal cell type. Thirty-seven patients were female and 49 male; 59 were rural and 27 urban; 36 cases had carcinoma in the colon and 50 in the rectum; and 55 were smokers and 31 non-smokers (Table 3).

\section{Mutation analysis of $A P C$}

The overall mutation rate of the MCR of $A P C$ among the 86 patients was 12.8 per cent (11 of 86). This is in contrast to other studies that have reported $A P C$ as the main gene to undergo aberration in CRC, with a frequency of about 60 per cent. DNA sequencing revealed four missense mutations, three nonsense mutations and four frameshift mutations, including three deletions and

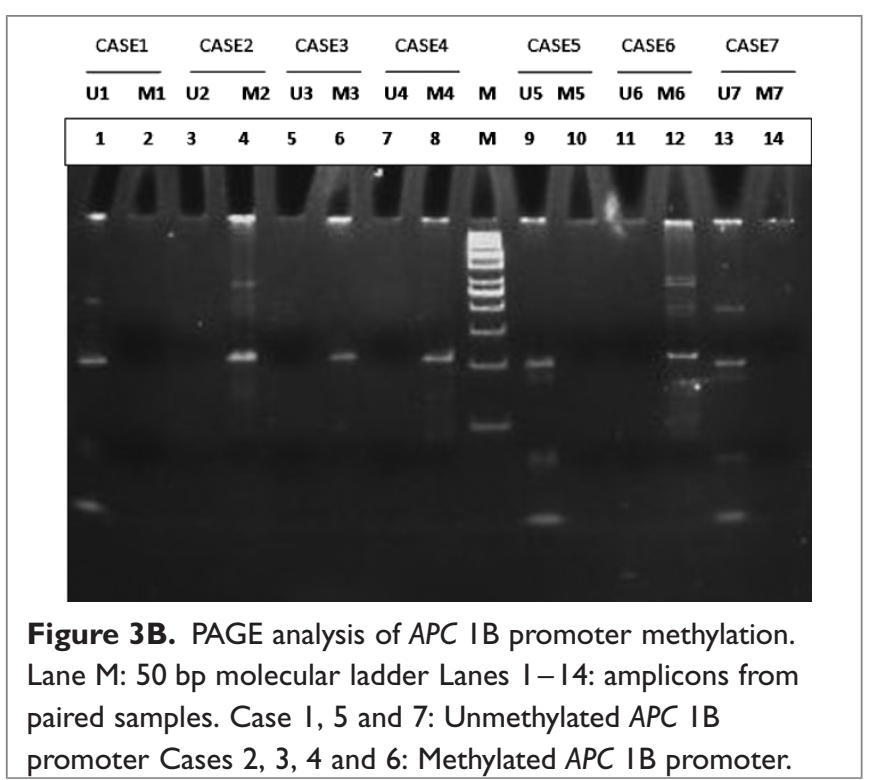


one insertion (Table 4, Figure 4). Among the three nonsense mutations, two were Leu $>$ Stop and one was Lys $>$ Stop.

Table 3. Clinico-epidemiological variables of the $86 \mathrm{CRC}$ patients versus 47 hypermethylated phenotypes of APC (IA and IB promoter) gene

$\begin{array}{lllll}\text { Variable } & \text { Total } & \text { Mutants }^{\mathrm{a}} & \text { Methylated }^{\mathrm{b}} & \mathrm{p} \\ & n=86 & n=I \mathrm{I} & n=47 & \text { value }^{\mathrm{c}} \\ & & (\mathrm{I} 2.79 \%) & (54.65 \%) & \end{array}$

$\begin{array}{lllll}\begin{array}{l}\text { Age group } \\ \leq 60\end{array} & 52(60.5 \%) & 5 & 20 & <0.05 \\ >60 & 34(39.5 \%) & 6 & 27 & \end{array}$

$\begin{array}{lllll}\text { Gender } & & & & \\ \text { Female } & 37(43.0 \%) & 4 & 19 & 0.85 \\ \text { Male } & 49(67.0 \%) & 7 & 28 & \end{array}$

$\begin{array}{lllll}\text { Dwelling } & & & & \\ \text { Urban } & 27(31.4 \%) & 5 & 17 & 0.70 \\ \text { Rural } & 59(68.6 \%) & 6 & 30 & \end{array}$

$\begin{array}{lllll}\begin{array}{l}\text { Tumour } \\ \text { location }\end{array} & & & & \\ \text { Colon } & 36(41.9 \%) & 8 & 29 & <0.05 \\ \text { Rectum } & 50(58.1 \%) & 3 & 18 & \end{array}$

$\begin{array}{lcccc}\begin{array}{l}\text { Nodal status } \\ \text { Involved }\end{array} & 48(55.8 \%) & 6 & 38 & <0.05 \\ \text { Not Involved } & 38(44.2 \%) & 5 & 9 & \\ \text { Tumour } & & & & \\ \text { grade } & & & & \\ \text { A + B } & 38(44.2 \%) & 5 & 9 & <0.05 \\ \text { C + D } & 48(55.8 \%) & 6 & 38 & \end{array}$

$\begin{array}{lllll}\begin{array}{l}\text { Smoking } \\ \text { status } \\ \text { Never }\end{array} & 31(36.0 \%) & 4 & 14 & 0.56 \\ \text { Ever } & 55(64.0 \%) & 7 & 33 & \end{array}$

\begin{tabular}{lllll}
$\begin{array}{l}\text { Bleeding PR/ } \\
\text { Constipation } \\
\text { No }\end{array}$ & $26(30.2 \%)$ & 2 & 16 & 0.69 \\
Yes & $60(69.8 \%)$ & 9 & 31 & \\
\hline $\begin{array}{l}\text { Pesticide } \\
\text { exposure }\end{array}$ & & & & \\
Never & $33(38.4 \%)$ & 3 & 19 & 0.85 \\
Ever & $53(61.6 \%)$ & 8 & 28 & \\
\hline
\end{tabular}

${ }^{a}$ Other than G > A transition at codon 1492 of APC.

${ }^{\mathrm{b}}$ Either IA or IB promoter hypermethylation.

'Fisher's two-tailed test for hypermethylation status of APC.
We also found a novel single nucleotide polymorphism (SNP) in our study, a G $>$ A polymorphism in codon 1492 of APC. The polymorphism changes ACG to ACA, without changing the resulting amino-acid residue. We found, that among 86 CRC cases, only 14 (16.3 per cent) had the homozygous wild-type (GG) genotype, while 53 (61.6 per cent) had the homozygous variant (AA) genotype and 19 (22.1 per cent) had the heterozygous (GA) genotype (Table 5, Figure 3). In addition, 72 cases had $G>A$ variants, 67 were variants for $\mathrm{G}>\mathrm{A}$ at codon 1492 only, while five also had mutations at other sites.

\section{Mutation analysis of the $\beta$-catenin gene}

The overall mutation rate of the $\beta$-catenin gene was 8.1 per cent (seven of 86). Of these seven mutations, three affected codon 32, three affected codon 49 and one affected codon 45 (Figure 5, Table 6); five were missense and two were nonsense mutations. Both nonsense mutations affected codon 49, changing lysine to a stop codon leading to truncation of the protein. In addition, five of the seven patients with $\beta$-catenin mutations had higher-grade tumours $(C+D)$. One also had a mutation in $A P C$, but six $\beta$-catenin had an intact $A P C$ gene.

\section{Hypermethylation of APC promoters}

Methylation analysis of $A P C$ carried out on two promoters, $1 \mathrm{~A}$ and $1 \mathrm{~B}$, revealed a high methylation status of these two promoters. Forty-seven (54.65 per cent) of the tumours were methylated at either one of the two promoter regions, while 39 (45.35 per cent) of the tumours were not methylated at any of the promoters (Tables 3 and 7). Among the tumours which were methylated, only nine (19.1 per cent) were found to be methylated at the $A P C$ 1A promoter exclusively, 15 (31.9 per cent) were found to be methylated at the $A P C 1 \mathrm{~B}$ promoter exclusively, while 23 (48.9 per cent) tumours were methylated at both promoters. Furthermore, we also found that only four tumours were mutated as well as hypermethylated for the $A P C$ gene 
Table 4. Nature of APC mutation cluster region mutations in II CRC patients from the Kashmir valley

\begin{tabular}{|c|c|c|c|c|}
\hline Patient ID & Mutation $^{\mathrm{a}}$ & Amino acid change & Affected codon & Effect \\
\hline A6 & $\mathrm{TTA}>\mathrm{TAA}$ & Leu $>$ Stop & 1277 & NS \\
\hline A8 & $\mathrm{ACCAA}>\mathrm{ACA}$ & Del CA & $1448 / 49$ & FS \\
\hline A9 & $\underline{\mathrm{TTA}}>\mathrm{GTA}$ & Leu $>$ Val & 1489 & MS \\
\hline $\mathrm{A} 22$ & $\mathrm{AGT}>\mathrm{A} T \mathrm{~T}$ & Ser $>$ Ile & 1494 & MS \\
\hline $\mathrm{A} 25$ & $\mathrm{AGA}>\mathrm{AGT}$ & $\operatorname{Arg}>\operatorname{Ser}$ & 1336 & MS \\
\hline $\mathrm{A} 27$ & $\mathrm{AGT}>\mathrm{A} T \mathrm{~T}$ & Ser $>\| l e$ & 1494 & MS \\
\hline A28 & TIA $>$ TAA & Leu $>$ Stop & 1277 & NS \\
\hline A3I & $\begin{array}{l}\text { TAAAAGAAAAG }> \\
\text { TAAAAGA }\end{array}$ & Del AAAAG & |307/08/09 & FS \\
\hline A33 & TAAAAG $>$ TAAG & Del AA & $1307 / 08$ & FS \\
\hline A37 & $\underline{A A G}>$ TAG & Lys $>$ Stop & 1449 & NS \\
\hline A77 & ATG $>$ ATAG & Ins $A$ & 1525 & FS \\
\hline$X X^{b}$ & $\mathrm{ACG}>\mathrm{ACA}$ & Thr $>$ Thr & 1492 & S \\
\hline
\end{tabular}

aMutated, deleted or inserted nucleotide underlined.

${ }^{b} \mathrm{XX}$ refers to any general tumour sample.

Abbreviations: MS, missense mutation; NS, nonsense mutation; S, silent mutation; FS, Frameshift mutation.

(Table 8). Statistical analysis showed a significant association between APC methylation status and the age group, tumour location (colon) and tumour grade $(\mathrm{C}+\mathrm{D})$ of the patients (Table 3$)$.

\section{Discussion}

The Kashmir valley, located in the northern division of India, has a unique ethnic population,
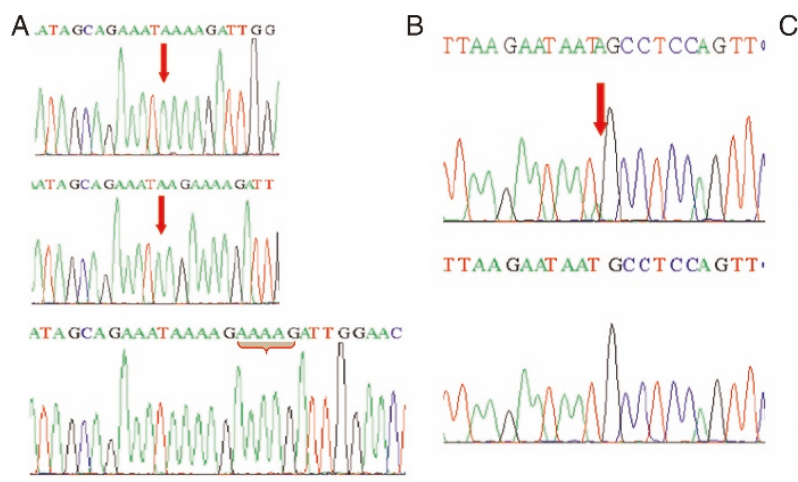

$C_{\text {CATtTt GCCACAGaAagtact }}$

TTAA GAAT AAT GCCT CCA GTT,
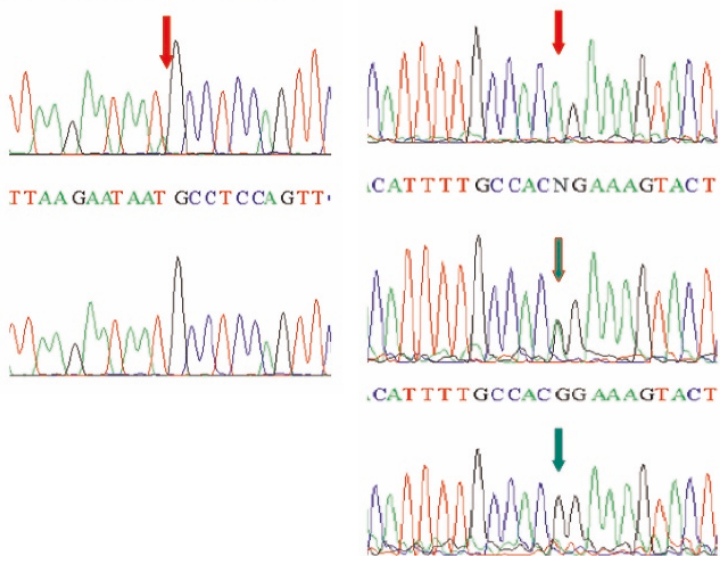

Figure 4. Partial electropherograms representing the mutant (above) and normal (below) forms (shown by arrows) of the mutation cluster region (MCR) of APC. (A) Deletion of the AAAAG pentamer at codons 1307/08/09 in the MCR region of APC and deletion of the AA dimer at codons $1307 / 08$ in the MCR region of APC. (B) Insertion of A at codon I525 in the MCR region of APC.

(C) Polymorphism of codon 1492 in the MCR region of APC. 
Table 5. Codon 1492 status of APC gene in 86 colorectal carcinoma cases in Kashmiri population

\begin{tabular}{|lc|}
\hline APC codon 1492 status & Cases $(n=86)$ \\
\hline Variant & $53(61.6 \%)$ \\
\hline Heterozygous & $19(22.1 \%)$ \\
\hline Wild-type & $14(16.3 \%)$ \\
\hline
\end{tabular}

living in temperate environmental conditions and with distinctive food habits, which, along with genetic factors, play a large role in the development of GIT cancers ${ }^{3-5,45}$. As previously reported, the aetiology and incidence of various GIT cancers in this population has been attributed to a probable exposure to nitroso compounds, amines and nitrates reported to be present in local foodstuffs such as hoakhe suen (sun-dried vegetables), pharei and hoggade (sundried and/or smoked fish and meat), hakh (a leafy vegetable of the Brassica family), hot noon chai (salted tea), dried and pickled vegetables and red chilli, and also through smoking hukka (a water pipe). ${ }^{2-5,46}$

According to the multi-step model of colorectal tumorigenesis, $^{7}$ the most common and principal causes of $A P C$ inactivation are gene aberrations. A

\section{CTCT GAGTGGTNÄAGGAATCCT}

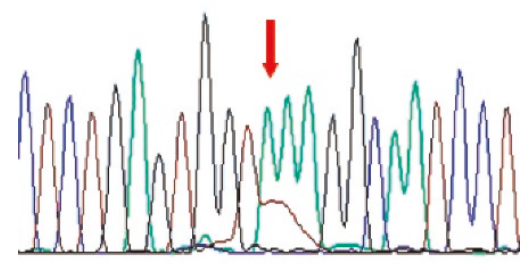

\section{CTCT GAGT GGTÄ̈ÄGGAATCCT}

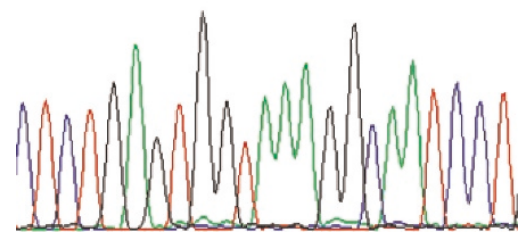

Figure 5. Partial electropherograms representing the mutant (above) and normal (below) forms (shown by arrows) of exon 3 of the $\beta$-catenin gene (AAA $>$ TAA).
Table 6. Nature of $\beta$-catenin gene in seven colorectal cancer patients from the Kashmir valley

\begin{tabular}{|lllcl|} 
Patient ID & Mutation $^{\text {a }}$ & $\begin{array}{c}\text { Amino } \\
\text { acid } \\
\text { change }\end{array}$ & $\begin{array}{c}\text { Affected } \\
\text { codon }\end{array}$ & Effect \\
\hline AI & GAC $>$ GGC & Asp $>$ Gly & 32 & MS \\
\hline A5 & AAA $>$ TAA & Lys $>$ Stop & 49 & NS \\
\hline A9 & $\underline{\text { AAA }>\text { TTA }}$ & Lys $>$ Leu & 49 & MS \\
\hline A10 & GAC $>$ GGC & Asp $>$ Gly & 32 & MS \\
\hline A62 & $\underline{\text { AAA }>\text { TAA }}$ & Lys $>$ Stop & 49 & NS \\
\hline A74 & GAC $>$ GGC & Asp $>$ Gly & 32 & MS \\
\hline A82 & TCCT $>$ TTT & Ser $>$ Phe & 45 & MS \\
\hline
\end{tabular}

a Mutated, deleted or inserted nucleotide underlined.

Abbreviations: MS, missense mutation; NS, nonsense mutation.

somatic mutation in $A P C$ leads to a truncated protein in most sporadic CRCs. ${ }^{15,36}$ Hypermethylation of $A P C$ at the promoter region constitutes an alternative mechanism for $A P C$ inactivation in breast, lung and GIT cancers, especially CRCs. ${ }^{30,33,34,38,40,47}$ Combined with these two mechanisms of $A P C$ inactivation and the aberrations in the $\beta$-catenin gene, the Wnt pathway molecules play an important role in CRC development and progression. ${ }^{48}$

The present study involved the mutational analysis of exon 15 (MCR) of $A P C$ and exon 3 of the $\beta$-catenin gene and also the hypermethylation analysis of two promoters of $A P C$. Although being the important genetic molecule of the Wnt pathway, and implicated in almost 60 per cent of sporadic CRCs, we found $A P C$ gene to be aberrant in only 12.79 per cent of CRCs, which was considerably lower than the previously reported frequencies. $^{9,19,35,50-53}$ This low frequency suggests that

Table 7. APC gene methylation status in 86 CRC cases in the Kashmiri population

$\begin{array}{lc}\text { APC promoter status } & \text { Cases }(n=86) \\ \text { Either methylated (IA and/or IB) } & \mathbf{4 7}(\mathbf{5 4 . 6 5 \% )} \\ \text { Only IA methylated } & 9 / 47(19.1 \%) \\ \text { Only IB methylated } & 15 / 47(31.9 \%) \\ \text { Both methylated } & 23 / 47(48.9 \%) \\ \text { Neither methylated } & \mathbf{3 9}(\mathbf{4 5 . 3 5 \% )}\end{array}$


Table 8. Correlation of APC mutation status versus APC methylation status

\begin{tabular}{|c|c|c|c|}
\hline & \multicolumn{2}{|c|}{ APC status } & \multirow[t]{2}{*}{ OR; $95 \% \mathrm{Cl}$; $\mathrm{p}$ value } \\
\hline & $\begin{array}{l}\text { Wild-type } \\
W=75\end{array}$ & $\begin{array}{l}\text { Mutant }^{\mathrm{a}} \\
M=\mathrm{II}\end{array}$ & \\
\hline \multicolumn{4}{|c|}{$A P C$ promoter methylation ${ }^{b}$} \\
\hline Unmethylated; $n=39$ & $32(42.7 \%)$ & $7(63.6 \%)$ & $2.35 ; 0.63-8.72 ; 0.22$ \\
\hline Methylated; $n=47$ & $43(57.3 \%)$ & $4(36.4 \%)$ & \\
\hline
\end{tabular}

APC may not be the foremost gene to be implicated in the development of CRCs in this population.

Furthermore, we found an $\operatorname{SNP}(G>A)$ at codon 1492 in 72 (83.7 per cent) CRC cases. Out of 72 cases, 53 were homozygous variants. This was a novel finding, as it has not been reported previously.

We also found a low frequency (8.1 per cent; seven of 86 ) of $\beta$-catenin mutations in CRC. These results were in line with those in the published literature. ${ }^{54-57}$ Exon 3 of $\beta$-catenin contains a regulatory domain which is the hotspot for genetic aberrations. Mutations in this exon have been reported in various tumours, resulting in its nuclear accumulation and leading to progression of the tumour. $9,43,58$ The mutations in the hotspot codons $-32,33,41,45$ and $49-$ in exon 3 of $\beta$-catenin result in an amino acid change at the GSK-3 $\beta$ phosphorylation sites, which in turn affect the phosphorylation mechanism and result in the decreased sequestration of $\beta$-catenin by $A P C .{ }^{58}$ Furthermore, the mutation affecting codon 45 (TCT $>$ TTT; Ser $>$ Phe) was present in a Lynch syndrome patient, as has been reported previously. ${ }^{55,56}$ Also, six of seven tumour samples which harboured $\beta$-catenin gene mutations were wild-type for APC (MCR only), which further corroborated findings in the literature that mutations of the genes encoding these two Wnt pathway molecules are mutually exclusive. $9,54,57,59,60$ Only one case (A9) had mutations in both genes (Tables 4 and 6). Overall, mutations in Wnt pathway molecule genes were found to be present in 20.9 per cent (18 of 86 ) of CRC cases.
Thus, our observation identifies this pathway as being important in determining the development and progression of CRC but is less important than in other populations, where the mutational frequency of these $W n t$ gladiators is higher.

CpG island hypermethylation is one of the important mechanisms of gene inactivation. Cancer cell lines have in general demonstrated an increased frequency of hypermethylation by comparison with primary tumours. ${ }^{61}$ Inactivation of tumour suppressor genes by promoter hypermethylation has been recognised to be as common as gene disruption by mutation in tumorigenesis. ${ }^{36,37,62,63} \mathrm{~A}$ number of studies on CRC around the globe have demonstrated the role of promoter hypermethylation of a number of different genes in the development and progression of CRC. ${ }^{32,64,65}$ Promoter hypermethylation of $A P C$, similarly to that of other genes, plays a pivotal role in the inactivation of $A P C$, which in turn enhances tumour development. ${ }^{30,33}$

In the present study, we found hypermethylation in 54.65 per cent $(47 / 86)$ of CRC cases, which is consistent with the results found in some other major studies, although markedly higher than reported in others. ${ }^{30,32,33}$ However, only 26.7 per cent $(23 / 86)$ of the tumours were hypermethylated at both the $1 \mathrm{~A}$ and $1 \mathrm{~B}$ promoters. This may be due to the fact that there is less mutational inactivation of $A P C$ in this population and also because this population is exposed to a special set of environmental challenges, such as extreme temperature, high altitude, special food habits and exposure to agricultural by-products such as pesticides and nitrosamines. ${ }^{5,46}$ As has been revealed in previous studies, promoter hypermethylation constitutes an 
alternative hit in the inactivation of $A P C$ in cancers, ${ }^{39,66}$ and we have identified the same phenomenon as the major cause of $A P C$ inactivation in our population. Various studies have shown transcriptional repression of $A P C$ by hypermethylation in tumours as well as cell lines. ${ }^{34,67}$

Arnold et al. demonstrated the loss of protein expression due to the promoter hypermethylation of $A P C .{ }^{39}$ In addition, 42.8 per cent (three of seven) of patients with a mutation in $\beta$-catenin were also found to have hypermethylation of $A P C$. We found the methylation status of the $A P C$ promoter to be associated with age $(>60)$, tumour location (colon) and nodal status/tumour grade $(\mathrm{C}+\mathrm{D})$ in CRC.

\section{Conclusion}

We conclude that, in the Kashmir valley population, although mutational aberration of the genes encoding two pivotal molecules of the Wnt pathway - APC and $\beta$-catenin - occurs at a low frequency in CRC cases, the high level of epigenetic silencing of $A P C$ plays a pivotal role in the initial tumorigenesis and also enhances the chances of tumour development and progression to advanced stages.

\section{References}

1. Center, M.M., Jemal, A., Smith, R.A. and Ward, E. (2009), 'Worldwide variations in colorectal cancer', CA Cancer J. Clin. Vol. 59 pp. 366-378.

2. Mir, M.M., Dar, N.A., Gochhait, S., Zargar, S.A. et al. (2005), 'p53 Mutation profile of squamous cell carcinomas of the esophagus in Kashmir (India): A high-incidence area', Int. J. Cancer Vol. 116, pp. $62-68$.

3. Murtaza, I., Mushtaq, D., Margoob, M.A., Dutt, A. et al. (2006), 'A study on pp53 gene alterations in esophageal squamous cell carcinoma and their correlation to common dietary risk factors among population of the Kashmir valley', World J. Gastroenterol. Vol. 12, pp. 4033-4037.

4. Sameer, A.S., Chowdri, N.A., Syeed, N., Banday, M.Z. et al. (2010), 'SMAD4 - Molecular gladiator of the TGF- $\beta$ signaling is trampled upon by mutational insufficiency in colorectal carcinoma of Kashmiri population: An analysis with relation to KRAS proto-oncogene', $B M C$ Cancer Vol. 10, p. 300

5. Sameer, A.S., Shah, Z.A., Syeed, N., Banday, M.Z. et al. (2010), 'TP53 Pro47Ser and Arg72Pro polymorphisms and colorectal cancer predisposition in an ethnic Kashmiri population', Genet. Mol. Res. Vol. 9, pp. 651-660.

6. Vogelstein, B., Fearon, E.R., Hamilton, S.R., Kern, S.E. et al. (1988), 'Genetic alterations during colorectal-tumor development', $N$. Engl. J. Med. Vol. 319, pp. 525-532.

7. Fearon, E.R. and Vogelstein, B. (1990), 'A genetic model for colorectal tumorigenesis', Cell Vol. 61, pp. 759-767.
8. Samowitz, W.S., Slattery, M.L., Sweeney, C., Herrick, J. et al. (2007), 'APC mutations and other genetic and epigenetic changes in colon cancer', Mol. Cancer Res. Vol. 5, pp. 165-170.

9. Narayan, S. and Roy, D. (2003), 'Role of APC and DNA mismatch repair genes in the development of colorectal cancers', Mol. Cancer Vol. 2, p. 41

10. Widelitz, R. (2005), 'Wnt signaling through canonical and noncanonical pathways: Recent progress', Growth Factors Vol. 23, pp. $111-116$.

11. Willert, K. and Jones, K.A. (2006), 'Wnt signaling: is the party in the nucleus?' Genes Dev. Vol. 20, pp. 1394-1404.

12. Mikesch, J.H., Steffen, B., Berdel, W.E., Serve, H. et al. (2007), 'The emerging role of Wnt signaling in the pathogenesis of acute myeloid leukemia', Leukemia Vol. 21, pp. 1638-1647.

13. Turashvili, G., Bouchal, J., Burkadze, G. and Kolar, Z. (2006), 'Wnt signaling pathway in mammary gland development and carcinogenesis', Pathobiology Vol. 73, pp. 213-223.

14. Yardy, G.W. and Brewster, S.F. (2005), 'Wnt signaling and prostate cancer', Prostate Cancer Prostatic Dis. Vol. 8, pp. 119-126.

15. Jass, J.R., Barker, M., Fraser, L., Walsh, M.D. et al. (2003), 'APC mutation and tumour budding in colorectal cancer', J. Clin. Pathol. Vol. 56, pp. 69-73

16. Polakis, P. (1997), 'The adenomatous polyposis coli (APC) tumor suppressor', Biochim. Biophys. Acta Vol. 1332, pp. 127-147.

17. Miyoshi, Y., Nagase, H., Ando, H., Horii, A. et al. (1992), 'Somatic mutations of the $A P C$ gene in colorectal tumors: Mutation cluster region in the APC gene', Hum. Mol. Genet. Vol. 1, pp. 229-233.

18. Beroud, C. and Soussi, T. (1996), 'APC gene: Database of germline and somatic mutations in human tumors and cell lines', Nucleic Acids Res. Vol. 24 , pp. $121-124$.

19. Behrens, J. (2005), 'The role of the Wnt signalling pathway in colorectal tumorigenesis', Biochem. Soc. Trans. Vol. 33, pp. 672-676.

20. Aoki, K. and Taketo, M.M. (2007), 'Adenomatous polyposis coli (APC): A multi-functional tumor suppressor gene', J. Cell Sci. Vol. 120, pp. $3327-3335$

21. Powell, S.M., Zilz, N., Beazer-Barclay, Y., Bryan, T.M. et al. (1992), 'APC mutations occur early during colorectal tumorigenesis', Nature Vol. 359 , pp. $235-237$.

22. Fodde, R., Kuipers, J., Rosenberg, C., Smits, R. et al. (2001), 'Mutations in the APC tumour suppressor gene cause chromosomal instability', Nat. Cell Biol. Vol. 3, pp. 433-438.

23. Oshima, M., Oshima, H., Kitagawa, K., Kobayashi, M. et al. (1995), 'Loss of $A p c$ heterozygosity and abnormal tissue building in nascent intestinal polyps in mice carrying a truncated Apc gene', Proc. Natl. Acad. Sci. USA Vol. 92, pp. 4482-4486.

24. Su, L.K., Kinzler, K.W., Vogelstein, B., Preisinger, A.C. et al. (1992), 'Multiple intestinal neoplasia caused by a mutation in the murine homolog of the APC gene', Science Vol. 256, pp. 668-670.

25. Ishikawa, T.O., Tamai, Y., Li, Q., Oshima, M. et al. (2003), 'Requirement for tumor suppressor Apc in the morphogenesis of anterior and ventral mouse embryo', Dev. Biol. Vol. 253, pp. 230-246.

26. Moser, A.R., Shoemaker, A.R., Connelly, C.S., Clipson, L. et al. (1995), 'Homozygosity for the Min allele of Apc results in disruption of mouse development prior to gastrulation', Dev. Dyn. Vol. 203, pp. 422-433.

27. Andreu, P., Colnot, S., Godard, C., Gad, S. et al. (2005), 'Crypt-restricted proliferation and commitment to the Paneth cell lineage following Apc loss in the mouse intestine', Development Vol. 132, pp. $1443-1451$.

28. Gounari, F, Chang, R., Cowan, J., Guo, Z. et al. (2005), 'Loss of adenomatous polyposis coli gene function disrupts thymic development', Nat. Immunol. Vol. 6, pp. 800-809.

29. Sansom, O.J., Reed, K.R., Hayes, A.J., Ireland, H. et al. (2004), 'Loss of Apc in vivo immediately perturbs Wnt signalling, differentiation, and migration', Genes Dev. Vol. 18, pp. 1385-1390.

30. Chen, J., Röcken, C., Lofton-Day, C., Schulz, H.U. et al. (2005), 'Molecular analysis of APC promoter methylation and protein expression in colorectal cancer metastasis', Carcinogenesis Vol. 26, pp. 37-43. 
31. Zare, M., Jazii, F.R., Alivand, M.R., Nasseri, N.K. et al. (2009), 'Qualitative analysis of adenomatous polyposis coli promoter: Hypermethylation, engagement and effects on survival of patients with esophageal cancer in a high risk region of the world, a potential molecular marker', BMC Cancer Vol. 9, p. 24.

32. Lind, G.E., Thorstensen, L., Løvig, T., Meling, G.I. et al. (2004), 'A $\mathrm{CpG}$ island hypermethylation profile of primary colorectal carcinomas and colon cancer cell lines', Mol. Cancer Vol. 3, p. 28

33. Kang, G.H., Lee, S., Kim, J.S. and Jung, H.Y. (2003), 'Profile of aberrant $\mathrm{CpG}$ island methylation along the multistep pathway of gastric carcinogenesis', Lab. Invest. Vol. 83, pp. 635-641.

34. Virmani, A.K., Rathi, A., Sathyanarayana, U.G., Padar, A. et al. (2001), 'Aberrant methylation of the adenomatous polyposis coli (APC) gene promoter 1A in breast and lung carcinomas', Clin. Cancer Res. Vol. 7, pp. 1998-2004.

35. Rowan, A.J., Lamlum, H., Ilyas, M., Wheeler, J. et al. (2000), 'APC mutations in sporadic colorectal tumors: A mutational "hotspot" and interdependence of the "two hits", Proc. Natl. Acad. Sci. USA Vol. 97, pp. $3352-3357$.

36. Esteller, M. and Herman, J.G. (2002), 'Cancer as an epigenetic disease: DNA methylation and chromatin alterations in human tumours', J. Pathol. Vol, 196, pp. 1-7.

37. Esteller, M., Sparks, A., Toyota, M., Sanchez-Cespedes, M. et al. (2000), 'Analysis of adenomatous polyposis coli promoter hypermethylation in human cancer', Cancer Res. Vol. 60, pp. 4366-4371.

38. Tsuchiya, T., Tamura, G., Sato, K., Endoh, Y. et al. (2000), 'Distinct methylation patterns of two APC gene promoters in normal and cancerous gastric epithelia', Oncogene Vol. 19, pp. 3642-3646.

39. Arnold, C.N., Goel, A., Niedzwiecki, D. and Dowell, J.M. (2004), 'APC promoter hypermethylation contributes to the loss of APC expression in colorectal cancers with allelic loss on 5q', Cancer Biol. Ther. Vol. 3, pp. 960-964.

40. Hiltunen, M.O., Alhonen, L., Koistinaho, J., Myöhänen, S. et al. (1997), 'Hypermethylation of the APC (adenomatous polyposis coli) gene promoter region in human colorectal carcinoma', Int. J. Cancer Vol. 70, pp. 644-648.

41. Debuire, B., Lemoine, A. and Saffroy, R. (2002), 'CTNNB1 (Catenin, beta-1)', Atlas of Genetics and Cytogenetics in Oncology and Haematology. http://AtlasGeneticsOncology.org/Genes/CTNNB1ID71.html.

42. Polakis, P. (2000), 'Wnt signaling and cancer', Genes Dev. Vol. 14, pp. 1837-1851.

43. Abraham, S.C., Wu, T.T., Klimstra, D.S., Finn, L.S. et al. (2001), 'Distinctive molecular genetic alterations in sporadic and familial adenomatous polyposis-associated pancreatoblastomas: Frequent alterations in the APC/beta-catenin pathway and chromosome 11p', Am. J. Pathol. Vol. 159, pp. 1619-1627

44. Hussain, I., ul Rehman, S., Afroze, D., Zahoor, L. et al. (2009), 'Mutational spectrum of conserved regions of TP53 and PTEN genes in Kangri cancer (of the skin) in the Kashmiri population', Mutat. Res. Vol. 676, pp. 5-10.

45. Salam, I., Hussain, S., Mir, M.M., Dar, N.A. et al. (2009), 'Aberrant promoter methylation and reduced expression of $p 16$ gene in esophageal squamous cell carcinoma from Kashmir valley: A high-risk area', Mol. Cell. Biochem. Vol. 332, pp. 51-58.

46. Siddiqi, M., Kumar, R., Fazili, Z., Spiegelhalder, B. et al. (1992), 'Increased exposure to dietary amines and nitrate in a population at high risk of esophageal and gastric cancer in Kashmir (India)', Carcinogenesis Vol. 13, pp. 1331-1335.

47. Das, P.M. and Singal, R. (2004), 'DNA methylation and cancer', J. Clin Oncol. Vol. 22, pp. 4632-4642

48. Schneikert, J. and Behrens, J. (2007), 'The canonical Wnt signaling pathway and its APC partner in colon cancer development', Gut Vol. 56, pp. $417-425$.
49. Karim, R.Z., Tse, G.M.K., Putti, T.C., Scolyer, R.A. et al. (2004), 'The significance of the Wnt pathway in the pathology of human cancers', Pathology Vol. 36, pp. 120-128.

50. Fearnhead, N.S., Britton, M.P. and Bodmer, W.F. (2001), 'The ABC of APC', Hum. Mol. Genet. Vol. 10, pp. 721-733.

51. Luchtenborg, M., Weijenberg, M.P., Roemen, G.M.J.M., de Bruine, A.P. et al. (2004), 'APC mutations in sporadic colorectal carcinomas from The Netherlands Cohort Study', Carcinogenesis Vol. 25, pp. $1219-1226$

52. Jeon, C., Lee, H., Shin, I.H. and Park, J. (2008), 'Genetic alterations of APC, K-ras, p53, MSI, and MAGE in Korean colorectal cancer patients', Int. J. Colorectal Dis. Vol. 23, pp. 29-35

53. Smith, G., Carey, F.A., Beattie, J., Wilkie, M.J.V. et al. (2002), 'Mutations in APC, Kirsten-ras, and p53 - Alternative genetic pathways to colorectal cancer', Proc. Nat Acad. Sci. USA Vol. 99, pp. 9433-9438.

54. Samowitz, W.S., Powers, M.D., Spirio, L.N., Nollet, F. et al. (1999), ' $\beta$-catenin mutations are more frequent in small colorectal adenomas than in larger adenomas and invasive carcinomas', Cancer Res. Vol. 59, pp. $1442-1444$

55. Miyaki, M., Iijima, T., Kimura, J., Yasuno, M. et al. (1999), 'Frequent mutation of beta-catenin and APC genes in primary colorectal tumors from patients with hereditary nonpolyposis colorectal cancer', Cancer Res. Vol. 59, pp. 4506-4509.

56. Johnson, V., Volikos, E., Halford, S.E., Eftekhar Sadat, E.T. et al. (2005), 'Exon $3 \beta$-catenin mutations are specifically associated with colorectal carcinomas in hereditary non-polyposis colorectal cancer syndrome', Gut Vol. 54, pp. 264-267.

57. Iwao, K., Nakamori, S., Kameyama, M., Imaoka, S. et al. (1998), 'Activation of the $\beta$-catenin gene by interstitial deletions involving exon 3 in primary colorectal carcinomas without adenomatous polyposis coli mutations', Cancer Res. Vol. 58, pp. 1021-1026.

58. Munemitsu, S., Albert, I., Souza, B., Rubinfeld, B. et al. (1995), 'Regulation of intracellular beta-catenin levels by the adenomatous polyposis coli (APC) tumor-suppressor protein', Proc. Natl. Acad. Sci. USA Vol. 92, pp. 3046-3050.

59. Sparks, A.B., Morin, P.J., Vogelstein, B. and Kinzler, K.W. (1998), 'Mutational analysis of the APC/beta-catenin/Tcf pathway in colorectal cancer', Cancer Res. Vol. 58, pp. 1130-1134.

60. Morin, P.J., Sparks, A.B., Korinek, V., Barker, N. et al. (1997), 'Activation of beta-catenin-Tcf signaling in colon cancer by mutations in $\beta$-catenin or APC', Science Vol. 275, pp. 1787-1790.

61. Paz, M.F., Fraga, M.F., Avila, S. and Guo, M. (2003), 'A systematic profile of DNA methylation in human cancer cell lines', Cancer Res. Vol. 63, pp. 1114-1121.

62. Karpiñski, P., Sasiadek, M.M. and Blin, N. (2008), 'Aberrant epigenetic patterns in the etiology of gastrointestinal cancers', J. Appl. Genet. Vol. 49, pp. $1-10$.

63. Jones, P.A. and Baylin, S.B. (2002), 'The fundamental role of epigenetic events in cancer', Nat. Rev. Genet. Vol. 3, pp. 415-428.

64. Lee, S., Hwang, K.S., Lee, H.J., Kim, J.S. et al. (2004), 'Aberrant CpG island hypermethylation of multiple genes in colorectal neoplasia', Lab. Invest. Vol. 84, pp. 884-893.

65. Toyota, M., Ahuja, N., Ohe-Toyota, M., Herman, J.G. et al. (1999), 'CpG island methylator phenotype in colorectal cancer', Proc. Natl. Acad. Sci. USA Vol. 96, pp. 8681-8686.

66. Goel, A., Arnold, C.N. and Boland, C.R. (2001), 'Multistep progression of colorectal cancer in the setting of microsatellite instability: New details and novel insights', Gastroenterology Vol. 121, pp. 1497-1502.

67. Moreno-Bueno, G., Hardisson, D., Sanchez, C., Sarrio, D. et al. (2002), 'Abnormalities of the APC/ $\beta$-catenin pathway in endometrial cancer', Oncogene Vol. 21, pp. 7981-7990. 